\title{
METHODS OF IMPROVING THE EFFICIENCY OF MONITORING OF CHANNEL DEFORMATIONS OF MOUNTAIN RIVERS NEAR BUILT-IN SETTLEMENTS: ON THE EXAMPLE OF THE BUKTYRMA RIVER
}

\author{
Talgat TAUKENOV*, Kulchikhan DZHANALEEVA, Zhuldyz YERZHANOVA \\ Department of Physical and Economic Geography, L. N. Gumilyov Eurasian National University, \\ Astana, Kazakhstan
}

Received 15 February 2018; accepted 14 March 2018

\begin{abstract}
The results of research on the development of methods for increasing the efficiency of monitoring the channel deformations of mountain rivers using the methods of aerospace studies of the Earth and geoinformation systems are presented. Examples are given of estimating channel deformations, compiling morphological characteristics of the valley, floodplain and river bed, determining the scheme for the development of channel processes using public space imagery, scientific justification for erosion control measures.
\end{abstract}

Keywords: channel deformations, erosion of river banks, types of river channel processes, monitoring the channel deformations, the methods of aerospace studies, erosion control measures.

\section{Introduction}

Channel deformations are among the dangerous geological processes associated with the action of permanent and temporary watercourses. Here the erosion of the banks is among the most dangerous processes. This risk is potential in many cases, because it is not directly related to economic damage. It is estimated when urban and rural settlements, industrial enterprises, engineering structures and economic objects are located on the eroded bank. In this case, the danger of riverbed deformations becomes real, leading to the destruction of objects and the violation of normal living conditions and people's activities.

Erosion of the bank caused by the influence of permanent watercourses takes place on all the mountain rivers in Kazakhstan. It appears especially on the large rivers during the spring-autumn floods, accompanied by landslide and avalanche-scree processes. Therefore, annually the erosion of the banks of mountain rivers brings considerable material damage to the population of the country - agricultural grounds, arable lands, vegetable gardens are destroyed, often residential and household buildings, power lines and communications, roads and bridges suffer.
The existing system of channel deformation monitoring includes the solution of the following main tasks:

1. assessment of the degree of danger for residential buildings and operating conditions of engineering structures, depending on local channel deformation;

2. compiling a forecast for the development of the riverbed for the coming years;

3. development of recommendations for the most effective protective measures to ensure the sustainable operation of engineering structures and the prevention of emergency situations.

Monitoring of channel deformations near populated areas and engineering facilities was carried out and carried out mainly by geodetic methods at stationary observation points. Such a method makes it possible to study local erosion of banks with high accuracy, but with a large number of sites and significant distances between them, it requires considerable time, material and financial resources. Also, the results of monitoring channel deformations by geodetic survey methods do not always reflect spatial changes in the structure of the valley and floodplain of the river.

Modern requirements to the effectiveness of channel deformation monitoring required the consideration of channel strain factors using geoinformation systems and

*Corresponding author. E-mail: talgat.taukenov@gmail.com 
remote sensing data along with geodetic methods. The use of aerospace monitoring methods is a necessary condition for regular observations of the current state of valley geosystems. Comparing them with the results of analyzes of aerospace images performed in the past decades, it is possible to accurately record the changes that have occurred.

Under the current conditions, research in the field of increasing the effectiveness of traditional ways of studying channel deformations, as well as the development of modern rational methods for monitoring them, have acquired great scientific and practical importance, which has made the study relevant.

In this paper, for the development of the methodology, the section of the Buktyrma River in the area of the Shyngystai village where the erosion of the left-bank ledge of the river has been eroded over the past 40 years has been chosen as an example to effectively solve the problems of channel strain monitoring. At the site currently under study, the riverbank is approaching the dwelling houses of the village, cutting the areas of vegetable gardens, pastures and destroying farm buildings (Figure 1). According to the villagers, in 1985-1990 years several projects have been developed to stabilize the shoreline of the river. However, none of them was implemented, including because of the ambiguous assessment of their effectiveness.

In the Buktyrma river basin riverbank erosion are particularly evident near the villages such as Arshaty, Kaiyndy, Enbek, Shyngystau, Parygino, Bykovo, Turgusun, as well as roads between Lesnaya pristan village - Zyryanovsk town, Zyryanovsk town - Parygino village, Kutikha village - Parygino village, Stepnoe village - Novaya Bukhtarma village, Katon-Karagay village - Uryl village, Zhazaba village - Uryl village. The erosion of the banks of the Buktyrma river near the above-mentioned settlements reaches up to 5 meters per year, which annually leads to the destruction of houses, engineering facilities and communications. For example, according to the Ministry of Emergency Situations of Republic of Kazakhstan, only in 2009, 22 houses, 60 yards, 675 plots of land and outbuildings, partially blurred roads with a total length of more than $5 \mathrm{~km}$, were flooded in the East Kazakhstan region. Six culverts with a diameter of 150-200 mm were washed away (Information Agency Kazakhstan Today/2009). This leads to increased attention to to monitoring the channel deformations of the Buktyrma river, forecast of scheduled riverbed deformations, which forms the basis for the design of anti-erosion measures.

Regular stationary observations of channel deformations of the Buktyrma River were carried out from 1982, with a break in 1993-2001 years and since 2002 year have been continued to the present time by the Department of Geology and Subsoil Use of the Committee of Geology and Subsoil Use of the Ministry of Investments and Development of the Republic of Kazakhstan.

The purpose of this work is to develop methods to improve the monitoring of channel deformations of mountain rivers through the integrated application of geodetic

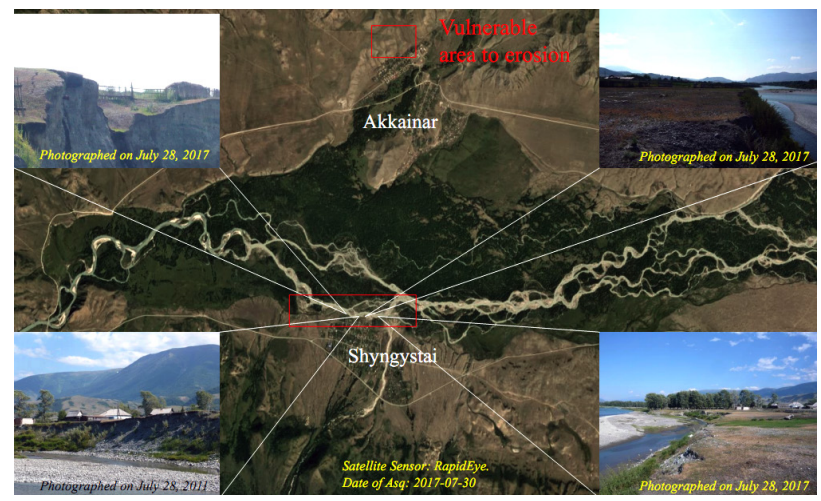

Figure 1. The erosion of the territory of Shyngystai village

and aerospace methods of Earth exploration. To achieve the research goal, the following tasks were solved for the investigated section of the river:

1. analysis of different maps and space images;

2. implementation of the assessment of the development of channel deformations;

3. identification of the main factors that determine the dynamics of the destruction of river banks;

4. conducting annual field studies on monitoring sites;

5. determination of the predictive scheme of deformation of the bed (type of channel processes).

The scientific fundamentals of the hydromorphological theory of the channel process, which is widely used at present to study and predict channel deformations, were laid in the 1950s-1960s. works of scientists N. E. Kondratiev, I. V. Popov, B. F. Snishenko (Kondratiev, Popov, \& Snischenko, 1982) and N. I. Makkaveev, R. S. Chalov (Makkaveev \& Chalov, 1986).

Scientific study of the deformations of riverbeds of the Altai rivers began in the 1950s. In different years, A. N. Mitrofanova, R. Sh. Kalita (Mitrofanova \& Kalita, 2012), G. I. Shamov (Shamov, 1959), L. S. Nurmagambetova, I. S. Sosedov (Nurmagambetova \& Sosedov, 1965), G. N. Skladchikova (Skladchikova, 1969), L. Yu. Chigrinets, M. M. Aznabakiev (Chigrinets \& Aznabakiyeva, 2010). Their works provide information on the magnitude of erosion of shores and destruction of populated areas, reconnaissance forecasts of bank processing, and analyze the factors of channel processes.

\section{Methodology and data}

During the investigations of channel and erosion processes of the Buktyrma River, a comparative cartographic method was applied. Geoinformation analysis was subjected to different maps and space images (Savinykh \& Tsvetkov, 2001). Assessment of channel deformations, analysis of the morphological characteristics of the valley and floodplain of the river in the area under investigation was carried out by methods of deciphering space images (Knizhnikov, Kravtsova, \& Tutubalina, 2014). To determine the type of channel processes, the methods of classifications and 
typifications of channel processes widely used in practice to date have been applied Kondratiev N. E., Popov I. V., Snischenko B. F. (Kondratiev et al., 1982).

The reliability of the conclusions and conclusions presented in the work is based on the hydromorphological theory of channel and erosion processes (Chalov, 2008). The results of the analysis of space images were compared and monitored with field data and results obtained by previous researchers.

To perform the research tasks, different maps, space images, hydrological posts and field observations were used the characteristics of which are given in Table 1.
The collected data were used in a complex manner to create a map of the Buktyrma River basin, to isolate its valley and to obtain morphological characteristics in the investigated area.

Space images with high spatial resolution proved to be very suitable for use in estimating riverbed deformations, erosion values and field observations planning. Field observations were conducted from 2011 to 2017. During the field work, points were chosen for carrying out observations and measurements. At each point, geodesic measurements were made-the distance from a permanently fixed reference point to the edge of the riverbed. To identify

Table 1. The data used for the study

\begin{tabular}{|c|c|c|c|c|}
\hline № & Spatial data & Dates of filming & $\begin{array}{l}\text { Scale/ } \\
\text { resolution }\end{array}$ & Obtained Sources \\
\hline 1 & Geodetic surveys of erosion processes. & $\begin{array}{l}1978 \\
1983 \\
1993\end{array}$ & $1: 2000$ & $\begin{array}{l}\text { From the archive of the East Kazakhstan } \\
\text { Interregional Department of Geology and } \\
\text { Subsoil Use. }\end{array}$ \\
\hline 2 & Topographical maps. & 1978 & $1: 100000$ & $\begin{array}{l}\text { Cartographic Web Service } \\
\text { http://loadmap.net/ }\end{array}$ \\
\hline 3 & Space images with high spatial resolution. & $\begin{array}{l}21.07 .2007 \\
15.07 .2012\end{array}$ & $1 \mathrm{~m}$ & $\begin{array}{l}\text { Geoinformation systems Google Earth Pro, } \\
\text { SasPlanet. }\end{array}$ \\
\hline 4 & $\begin{array}{l}\text { Space images with a medium spatial } \\
\text { resolution: RapidEye. }\end{array}$ & 30.07 .2017 & $5 \mathrm{~m}$ & $\begin{array}{l}\text { Geoinformation system } \\
\text { Planet Explorer } \\
\text { https://www.planet.com } \\
\text { Trial access. }\end{array}$ \\
\hline 5 & $\begin{array}{l}\text { Space images with low spatial resolution: } \\
\text { 1) Landsat } 5 \text { MSS, } 4 \text { TM, } 5 \text { TM, } 7 \text { ETM +, } \\
8\end{array}$ & $\begin{array}{l}1975 \\
1979 \\
1992 \\
2007 \\
2017\end{array}$ & $30-90 \mathrm{~m}$ & $\begin{array}{l}\text { Site of the United States Geological Survey } \\
\text { http://earthexplorer.usgs.gov/ }\end{array}$ \\
\hline & 2) Sentinel -2 & 04.08 .2017 & $10-60 \mathrm{~m}$ & $\begin{array}{l}\text { Geoinformation system } \\
\text { Sentinel Hub https://apps.sentinel-hub.com }\end{array}$ \\
\hline 6 & Digital Elevation Model SRTM. & 11.02 .2000 & $30 \mathrm{~m}$ & $\begin{array}{l}\text { Site of the United States Geological Survey } \\
\text { http://earthexplorer.usgs.gov/ }\end{array}$ \\
\hline 7 & $\begin{array}{l}\text { Field observations along river lines, on sites } \\
\text { of the destroyed bank: maps of changes in } \\
\text { bank status at a scale of 1:2000; geological } \\
\text { and geomorphological descriptions. }\end{array}$ & $2011-2017$ & $1: 1000$ & $\begin{array}{l}\text { Field data obtained by the authors of the } \\
\text { article }\end{array}$ \\
\hline 8 & $\begin{array}{l}\text { The hydrological regime of the Buktyrma } \\
\text { river near Berel, Pechi, Lesnaya Pristan, } \\
\text { Uryl, Chernovoye, Beloye, Turgusun: } \\
\text { monthly/yearly average water levels. }\end{array}$ & $2010-2017$ & $\begin{array}{l}\text { Hydrological } \\
\text { stations }\end{array}$ & $\begin{array}{l}\text { East Kazakhstan Center for } \\
\text { Hydrometeorology }\end{array}$ \\
\hline 9 & $\begin{array}{l}\text { Geological map of the Kazakh Soviet } \\
\text { Socialist Republic: M-45-B. }\end{array}$ & 1979 & $1: 500000$ & $\begin{array}{l}\text { Geological library GeoKniga } \\
\text { www.geokniga.org }\end{array}$ \\
\hline 10 & $\begin{array}{l}\text { National Atlas of the Republic of } \\
\text { Kazakhstan. Vol. 1: Geomorpholog. }\end{array}$ & 2010 & $1: 500000$ & \multirow{3}{*}{$\begin{array}{l}\text { National Library of the Republic of } \\
\text { Kazakhstan } \\
\text { https://nlrk.kz/ }\end{array}$} \\
\hline 11 & $\begin{array}{l}\text { Atlas of natural and technogenic hazards } \\
\text { and risks of emergency situations in the } \\
\text { Republic of Kazakhstan. } \\
\text { The danger of the erosion and soil blowing. }\end{array}$ & \multirow[t]{2}{*}{2010} & $1: 5000000$ & \\
\hline 12 & $\begin{array}{l}\text { Atlas of natural and technogenic hazards } \\
\text { and risks of emergency situations in the } \\
\text { Republic of Kazakhstan. } \\
\text { The risk of bank erosion: Lake Zhaisan and } \\
\text { Buktyrma reservoir. }\end{array}$ & & $1: 500000$ & \\
\hline
\end{tabular}


various alluvial forms on the floodplain, field observations were carried out in summer flood and autumn low water.

\section{Study area}

The Buktyrma River belongs to the basin of the Arctic Ocean and is the largest of the Altai tributaries of the Ertis River. Its basin is located within the South-Western Altai, in the southern half of the temperate climatic belt. Buktyrma flows into the Buktyrminskoe reservoir on the right (Dzhanaleeva, 2010). Its length, after flooding part of the valley with the waters of the Buktyrminsky reservoir, is $336 \mathrm{~km}$, the basin area is $12,660 \mathrm{~km}^{2}$. The structure of river systems, hypsometric characteristics and the catchment area of the Buktyrma river are shown on the map of the river basin (Figure 2).

A map was built based on the SRTM digital elevation model using Spatial Analyst tools of ArcGIS geoinformation system 10.3 (Djokic \& Zichuan, 2011).

The Buktyrma river begins from the small mountain lake of Buktyrminskoe, but the true sources of it are the Belaya Buktyrma river, which originates at an altitude of more than 3,000 m, in the region of Kanas glaciers and the Chindagatui and the Berel rivers, also flowing from glaciers. Chindagatui flows from the Argut range, and Berel from the slopes of the Belukha mountain (Boldyrev, 1978).

The upper reaches of the Buktyrma closely adjoin the upper reaches of the Katun river and the Argut river. As a result of bifurcation, the water of the mountain stream is divided into two branches, one of which gives rise to the Black Berely River (Buktyrma Basin), and the other to the Koksu Argutinskaya River (Katun Basin). The origins of the Buktyrma (the rivers Chindagatui, Belaya Buktyrma, Black and White Berel, etc.) flow in narrow gorges and abound with waterfalls and cascades.

The Buktyrma flows in a wide valley below the Belaya Berely River (Uryl, Kayyndy, Enbek, Akkaynar, Shyngystai rural settlements), reaching $4-5 \mathrm{~km}$ in width. The most significant expansion of the Buktyrminskaya Valley in this part of the river is between the Arcadian Gates and the Bolshoi Porog (228 km from the mouth). The river flows in a narrow valley in the north-west direction below the great threshold. The Buktyrma (rural settlements of Lesnaya pier, Parygino, Turgusun) looks like a plain river below the mouth of the Khamir River, its banks become lower, the floodplain is widened, the riverbed is broken up into sleeves.

The terrain of the area adjacent to the Buktyrma River valley from the mouth of the Chernova River to the Khamir River is mountainous, heavily dissected, with steep slopes. During the spring flood, $50-60 \%$ of the floodplain is flooded with a layer of $0.5-1.0$ meters in the middle years of water. In flooded years floodplain is flooded completely. The rise of water above the surface of the floodplain reaches $1.5-2.0 \mathrm{~m}$.

Buktyrma has stretched flood of multi-comb swing level and a water flow coming usually from April to June. In the middle current, the rise in the level of the Buktyr$\mathrm{ma}$ in the high water ranges from $0.7 \mathrm{~m}$ to $2.5 \mathrm{~m}$. At this time, the water flow is increased 2.7 times. The duration of the flood is due to sequences of snowmelt at different heights and the imposition of rainfall floods (spring rain). During the melting of snow, Buktyrma turns into a raging stream, ruining the banks, tearing up the trees. In midsummer the second flooding (from melting ice) with the lifting height and the level of $0.5-1.0 \mathrm{~m}$. passes in the Buktyrma. Winter level fluctuations are insignificant. In the low water, the river reduces the runoff to 10 cubic $\mathrm{m} / \mathrm{sec}$. The annual flow of water in the tributaries of the Buktyrma in the middle of the currents is distributed unevenly. There is $60-70 \%$ of the annual runoff over the three spring months, $20-30 \%$ - in the summer and autumn and only $10 \%$ falls on the winter (Semenov, 1986). Accordingly, the most active bank washouts occur in the spring, and the higher water levels rise in rivers, the more erosion occurs.

The investigated section of the river is in the area of the village of Shyngystai of the Katon-Karagai district of

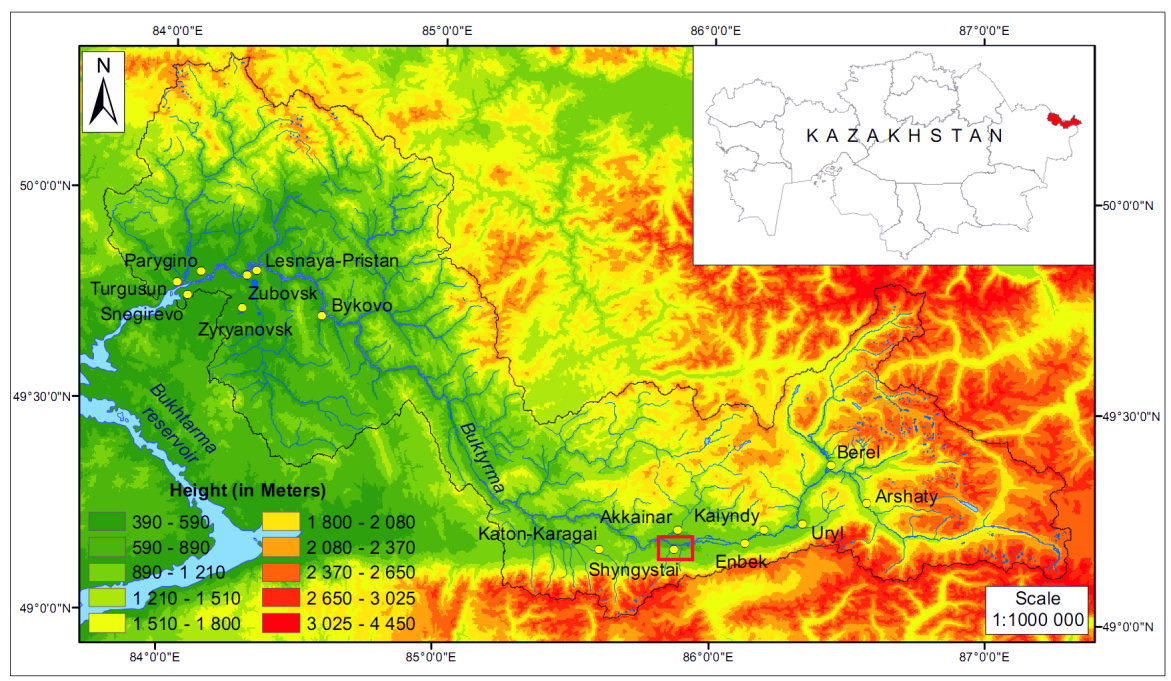

Figure 2. Map of the Buktyrma river basin 
the East Kazakhstan region. About 800 people live in the village.

In physical and geographical terms, the investigated section of the river is in the middle current of the Buktyrma River, where the river flows along the Shyngystai intermountain area of the Narym-Buktyrma Valley, an intermontane hollow between the ridges of the Southern Altai (in the south) and mountain massifs on the right bank (in the north and east) with steppe and meadow vegetation and the mountain lanes separating them, covered with deciduous and pine forests. Here, the Buktyrma is divided into a number of sleeves with blockages with a flow velocity of $1.1 \mathrm{~m} / \mathrm{s}$ (Hydrological yearbooks of the rivers of the Ob and Irtysh basin, 1954-1999).

Geomorphologically, the investigated section of the river is located in the valley of the Buktyrma River in the place where the upper quaternary cone of the Kokterek River is discharged into it. The surface of the cone of removal is located at absolute elevations of 920-950 m, slightly processed by water streams.

In the geological structure, the investigated section of the river consists mainly of loose quaternary deposits. Loams, sandy loams with an admixture of gravel, gruss and underlying gravel-pebbles with small boulders with sandy aggregate are exposed to erosion and collapse. Geomorphological conditions and lithology of alluvial deposits of both floodplain and above-floodplain terraces determine the free conditions of riverbed deformations along the width of the river valley.

\section{Results}

Evaluation of riverbed deformations. The planned deformation of the riverbed of the Buktyrma River in the investigated area was estimated by determining the displacement of the channel edge for different years. To do this, with the help of geo-information systems Google Earth Pro, SasPlanet and ArcGIS, a comparative analysis of different maps and space images was carried out. During the analysis all cartographic materials were brought to a unified system of coordinates and combined to reveal changes in contours of the riverbed (Figure 3).
The analysis made it possible to establish the direction of the river bank displacement, to identify the points of the most intensive erosions and to determine the quantitative scouring indices for each of them (Table 2).

Table 2. Quantitative indicators of erosion of the Buktyrma River bank

\begin{tabular}{|c|c|c|c|}
\hline Profile \# & $\begin{array}{c}\text { The amount } \\
\text { of erosion for } \\
\text { the period } \\
\text { from 1978 } \\
\text { to 2017, in } \\
\text { meters }\end{array}$ & Profile \# & $\begin{array}{c}\text { The amount } \\
\text { of erosion for } \\
\text { the period } \\
\text { from 1978 } \\
\text { to 2017, in } \\
\text { meters }\end{array}$ \\
\hline 1 & 55.6 & 5 & 182.7 \\
\hline 2 & 128.0 & 6 & 159.9 \\
\hline 3 & 127.1 & 7 & 205.7 \\
\hline 4 & 132.5 & 8 & 162.9 \\
\hline
\end{tabular}

As a result, it is established that the profile area has been most intensively eroded during the last 39 years. The erosion of the bank has reached $205.7 \mathrm{~m}$. The erosion of the banks in the regions of profiles 5 and 8 was also significant during this period. The displacement of the bankboulders was $182.7 \mathrm{~m}$ and $162.9 \mathrm{~m}$, respectively. Flushing of the banks in the western part of the village occurs at a more moderate rate compared to the eastern part.

Thus, as a result of a comparative analysis of the different maps and space images, it was revealed that erosion is developing everywhere along the bankline of the Buktyrma river, but with different erosion values. The total length of the eroded bank reaches up to $1.5 \mathrm{~km}$.

Investigation of the intensity of past coastal deformations is the basis for predicting the future situation of eroded banks of the river.

Morphological characteristics of the investigated section. In the region of the valley, the Buktyrma river is well-defined, with a width of $4-5 \mathrm{~km}$, and is bounded on both sides by slopes of ridges. On the three-dimensional digital relief model, the edges and slopes of the valley were clearly visible. The bottom of the valley is dissected by ducts and stems, along which the entire flow of the river

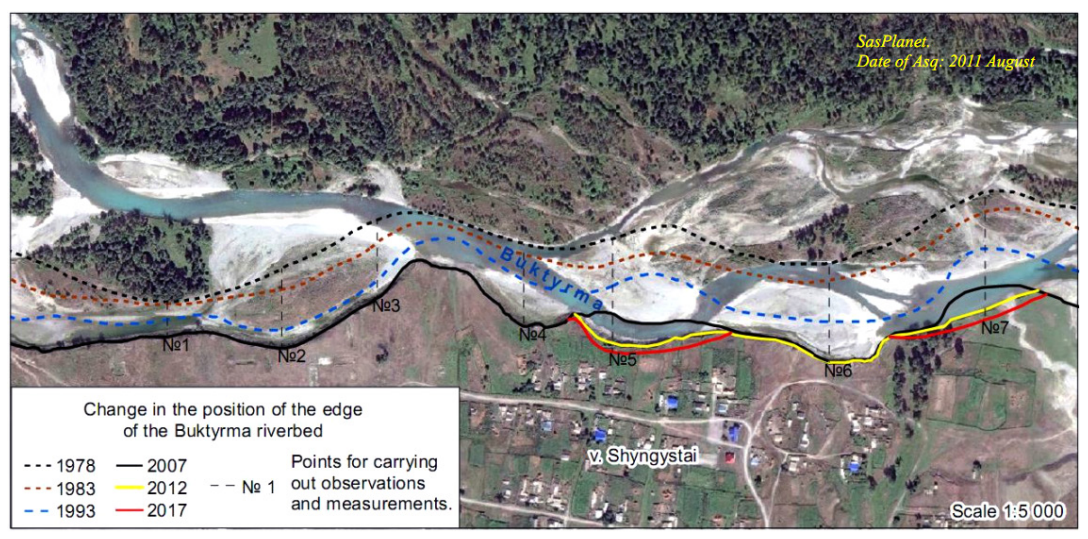

Figure 3. Change in the position of the edge of the Buktyrma riverbed in the area of the Shyngystai village 
is distributed. During the passage of floods, changes occur in the position of the duct and hoses, erosion of some riverbed forms and the formation of others.

The right bank of the valley is above the left bank, it has a rocky ledge in the riverbed of the Buktyrma canals, with absolute marks of $877-880 \mathrm{~m}$. Here is the village of Akkaynar.

The floodplain terrace is developed in the left bank of the Buktyrma Valley, forming a ledge above the water level of 5.5-10.4 $\mathrm{m}$ in height. The surface of the terrace with absolute elevations of 873-876 m, flat-wavy, riddled with temporary watercourses, is slightly inclined to the river. Transporting a significant amount of loose material to the floodplain, a cone of the Kokterek River is being pushed out. Floodplain vegetation is represented by herbaceous and arboreal shrub vegetation. Traces of fallen trees as a result of erosion are observed.

The bed of the Buktyrma river in the investigated area is a multi-arm and the main riverbed is pressed to the left bank of the valley. The width of the riverbed is $50-60 \mathrm{~m}$ with a depth of $0.8-1.8 \mathrm{~m}$. The bottom of the bed is pebbly, with rolling and to a considerable extent drifting in riverbed periods by riverbed islands.

On space images with a high spatial resolution, in the region of profiles 1, 6 and 8, the floodplain islands cut off by the Buktyrma canals are seen, and in the region of profiles 2,3 and 5 the partially bedded vegetation is riverbed islands. At different times, satellite images show the appearance and disappearance of new riverbed islands and the riverbed. On the adherents of some riverbed islands there are visible tree heaps and blockages in the entrances to the small riverbeds.

Determination of the type of the riverbed process. According to the hydromorphological theory of the riverbed process by Kondratyev N. E. et al. and methods for the typification of riverbeds of mountain rivers Kopaliani Z. D. and Romashin V. V. (Kopaliani \& Romashin, 1970), each type of riverbed process is formed with a natural combination of determining factors: limiting conditions, water and sediment discharge. Specificity of these combinations is reflected in the structure of the valley, floodplain, and riverbed. The features of each type are depicted in satellite imagery and are identified with the help of characteristic complex features that are recognized easier or more difficult depending on the scale of the images, the water level and the phenological phase of the vegetation cover. The main complex feature in distinguishing the type of riverbed processes is the pattern of the bed and the floodplain, on which the form of the object is relatively unchanged and the tone of the individual parts of the image changes significantly in time: the open water surface, the intrusive morphological formations and vegetation.

The type of riverbed processes on the investigated section of the Buktyrma river is defined as "mountain floodplain mantle" as a result of the analysis of the signs of the type of riverbeding by the presence of floodplain and riverbed islands of different size and shape, a number of slightly sinuous different widths of hoses forming a tie into the floodplain and a peculiar wavy-net pattern of the bed.

Forecast of riverbed deformations. The erosion of the banks of the Buktyrma River in the middle current in the area of the Shyngystai village occurs as a result of the connection with time of shallow small riverbeds dissected along the bottom of the valley in the form of wide sleeves in the left bank of the valley. As a result, the ledge of the left above-floodplain terraces of the Buktyrma River, folded mainly from loose materials, has been gradually eroding since 1978 and retreated to more than $205 \mathrm{~m}$ before 2017.

In the course of the study, it was found that the erosion of river banks occurs as a result of the direct action of water flow on soils represented by small particles and is activated during the high water level.

One of the signs of this form of erosion of the coastal ledge is the often observed dangling over the water of the sod, from under which the soil is washed. All the incoming material during the erosion and collapse of the coastal ledge is quickly mixed and moved to suspended matter, accumulating downstream in the form of channel islands and ridges.

An analysis of the quantitative indicators of erosion and maps obtained in the course of the study alsou shows that none of the determined indices change uniformly and there is no clear trend in the change in erosion rates over time.

Thus, according to the type of riverbed processes, planned deformations on the investigated section of the Buktyrma River as a whole lead to a gradual development of the riverbed and the main riverbed within the belt of riverbed formation, their dying and renewal accompanied by a redistribution of water flow between them. The belt of riverbed formation in the investigated section of the river is the entire width of the bottom of the river valley and was determined in the course of the study, taking

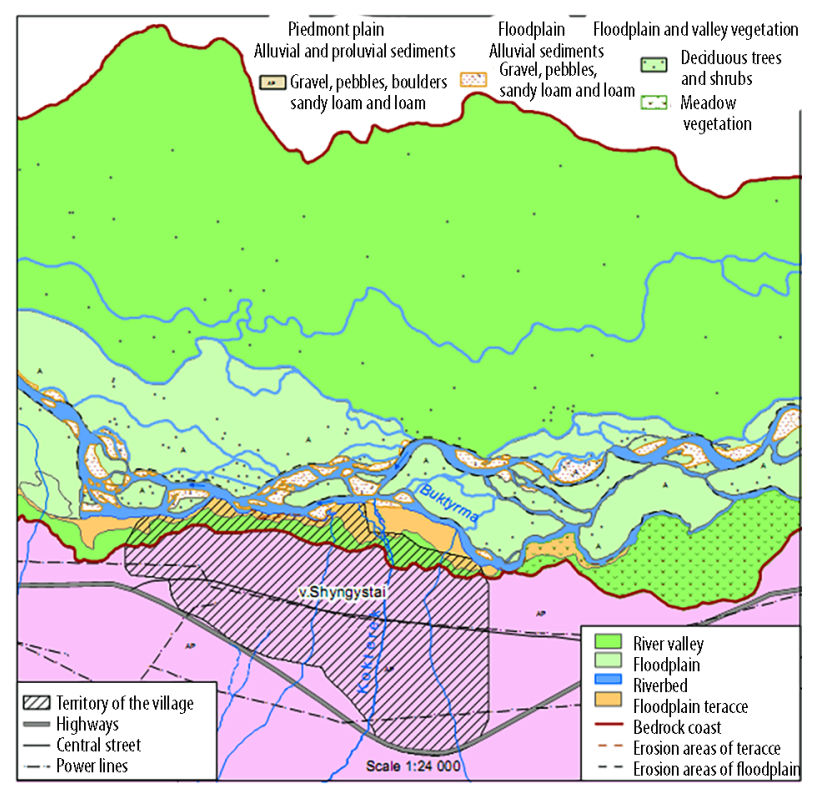

Figure 4. Scheme of eroded areas of the Buktyrma River near Shyngystai village 
into account the monitoring of the spatial variation of the riverbed and floodplain streams. In the future, unmilled single-hose riverbeds can branch out and become multihosed according to the scheme for the development of the flood-plain multi-hood, and new riverbed islands, overloaded with sediments, also form within individual riverbeds. At the same time, the erosion of the banks will occur both to the right and to the left along the river (Figure 4).

Planned deformations of the channel and, respectively, erosion of the banks of the Buktyrma River in the area of the Shyngystai village will also continue, and in the absence of measures to protect the populated area from further erosion, the danger of destruction of the riverside area of the village will be preserved within the belt of the river bed formation. Protection of the settlement is possible through the strengthening of the coastline within the boundaries of the village, clearing and straightening the old riverbed and channels of secondary channels. This will redistribute the flow of water and direct the main flow through the central channel of the valley and, as a result, the probability of erosion of the settlement will decrease.

Further investigation of planned deformations of the Buktyrma riverbed in the area near the village of Shyngystai is advisable to continue on the basis of stationary and aerospace observations, which is typical for other sections of the river as a whole. This will provide an actual material on the deformations of the river bed and floodplain. The received materials will serve for development of scientific bases of designing of protective actions of settlements and other technical constructions from erosion.

\section{Conclusions}

Significant deformations of the riverbeds of Buktyrma's river basin caused necessity of implementation of constant monitoring of channel deformations near settlements and important engineering-economic objects. The basic task of monitoring of channel deformations is supplying by operational and accurate information of erosion of coasts, the dynamics of channel deformations and structural components of valleys, flood-lands and the beds of rivers.

Increase of efficiency of monitoring of channel deformations will become possible at the expense of complex application of modern methods of aerospace researches of Earth and geoinformation systems. At the same time predictive models of dynamics of channel deformations and structural components of valleys, flood-lands and the beds of rivers should be based on known hydromorphological theory of channel and erosion processes.

As well it is to be noted that use of aerospace imageries and topographical maps of different scales for evaluation of channel deformation at the expense of their different degree of generalization can lead to errors in accuracy. Application of received specifications of erosion for forecasting can lead to errors of forecasts in hundreds of percent. Nevertheless, at absence of other materials, application of such data is justified, for example, at constitution of qualitative opinion of slowing down or erosion intensification.

To use in actual practice of methodical bases developed during given research allows to raise efficiency of monitoring of channel deformations and works in solving problems of forecasting channel and erosional processes of mountain rivers and preventing emergencies associated with them.

\section{Author contributions}

Talgat Taukenov conceived, wrote and edited the paper. Kulchikhan Dzhanaleeva and Zhuldyz Yerzhanova contributed to the text and edited the paper. Talgat Taukenov designed and prepared maps for Figures. The authors' names are provided in the order of contribution.

\section{Disclosure statement}

The authors declare no conflict of interest.

\section{References}

Boldyrev, M. V. (1978). Rivers of Eastern Kazakhstan (pp. 106120). In Natural conditions and natural resources of East $\mathrm{Ka}$ zakhstan. Alma-Ata: (Nauka) Science.

Cartographic Web Service. (2017). Retrieved from http://loadmap.net/

Chalov, R. S. (2008). Volume 1: Channel processes: factors, mechanisms, forms of manifestation and conditions of the formation of river channels (608 p.). River channel science: theory, geography, practice. Moscow: Edition LKI.

Chigrinets, L. Y., \& Aznabakiyeva, M. M. (2010, April). Assessment of erosion activity of rivers in the Kazakhstani sector of the Mountain Altai using data on sediment loads. The Ministry of Education and Science of the Republic of Kazakhstan. The Al-Farabi Kazakh National University. In Materials of the International Scientific and Practical Conference "Current trends in development of geographical science in the Republic of Kazakhstan" (pp. 127-1370). Almaty.

Djokic, D., \& Zichuan, Y. (2011 April 10). DEM preprocessing for efficient watershed delineation. Esri.

Dzhanaleeva, K. M. (2010). Physical geography of the Republic of Kazakhstan (pp. 290-298). Astana.

Geoinformation system Planet Explorer. (2017). Retrieved from https://www.planet.com

Geoinformation system Sentinel Hub. (2017). Retrieved from https://apps.sentinel-hub.com

Geological library GeoKniga. (2017). Retrieved from www. geokniga.org

Hydrological yearbooks of the rivers of the $\mathrm{Ob}$ and Irtysh basin. (1954-1999). Materials of the Fund of the East Kazakhstan Hydrometeorology Center.

Information Agency Kazakhstan Today. (2009). In the East Kazakhstan region as a result of floods, 22 houses, 60 households, 675 land plots and 675 household outbuildings were flooded the Ministry of Emergency Situations of the Republic of $\mathrm{Ka}$ zakhstan. Retrieved from https://www.kt.kz/rus/incidents/v_ vko_v_rezuljtate_pavodkov_bilo_podtopleno_22_doma_60_ dvorov_675_zemeljnih_uchastkov_i_hozpostroek_mchs_ rk_1153482912.html

Knizhnikov, Y. F., Kravtsova, V. I., \& Tutubalina, O. V. (2014). Aerospace methods of geographic researches. Moscow: Academia. 
Kondratiev, N. E., Popov, I. V., \& Snischenko, B. F. (1982). Fundamentals of the hydromorphological theory of the channel process (272 p.). Leningrad: Hydrometeoizdat.

Kopaliani, Z. D., \& Romashin, V. V. (1970). Problems of channel dynamics of mountain rivers. Proceedings of the State Hydrological Institute (183 ed.) (pp. 81-98). Leningrad: Hydrometeoizdat.

Makkaveev, N. I., \& Chalov, R. S. (1986). Channel processes (263 p.). Moscow: MSU Press.

Mitrofanova, A. H., \& Kalita, R. Sh. (2012, November). Assessment of risks of dangerous exogenetic processes in the shoreline of the Buktyrma reservoir and Lake Zhaisan (pp. 57-63). Series of geology and technical sciences, 6(440). News of the National academy of sciences of the Republic of Kazakhstan. Almaty, NAS RK.

National Library of the Republic of Kazakhstan. (2017). Retrieved from https://nlrk.kz/
Nurmagambetova, L. S., \& Sosedov, I. S. (1965). Annual fluctuations in river discharges of Eastern Kazakhstan. Questions of Geography of Kazakhstan, 2, 141-150. Alma-Ata: Nauka (Science).

Savinykh, V. P., \& Tsvetkov, V. Y. (2001). Geoinformation analysis of remote sensing data. Moscow: Kartgeotsenter - Geodezizdat.

Semenov, V. A. (1986). Surface water resources (216 p.). Hydrological study. Moscow: Hydrometeoizdat.

Shamov, G. I. (1959). River sediments (378 p.). Leningrad: Hydrometeoizdat.

Site of the United States Geological Survey. (2017). Retrieved from http://earthexplorer.usgs.gov/

Skladchikova, G. N. (1969). Sediment run-offs (pp. 176-196). Volume 15: USSR Surface Water Resources (1 ed.). Leningrad: Hydrometeoizdat. 